\title{
Samaria-Sebaste Portrait of a polis in the Heart of Samaria
}

\author{
Arthur Segal
}

\begin{abstract}
King Herod of Iudaea (37-4 BCE) was a great master builder of the late Hellenistic and early Roman era. The two most important building enterprises initiated by him were the city and the port of Caesarea Maritima and Samaria-Sebaste. Both cities were named in honor of the Caesar Augustus and in each of these cities he erected temples dedicated to the Imperial cult. Among various public compounds erected in Samaria-Sebaste, such as the forum and the basilica, we find a gymnasium-stadium complex. The very existence of the latter testifies to the character of Samaria-Sebaste as the real polis populated mainly by the Hellenized Syro-Phoenicians. While the establishment of Caesarea Maritima with its port was a political-ideological declaration, Samaria-Sebaste was above all a power base and a stronghold loyal to the king.
\end{abstract}

Keywords: king Herod of Iudaea, town-planning, Augusteum, public compounds

Arthur Segal (Emeritus), Zinman Institute of Archaeology, University of Haifa, Haifa; asegal@research.haifa.ac.il

The city of Samaria was named for the geographical region of the Samarian mountains within which it is located. It has been identified with the present-day Arab village of Sebastia, about $10 \mathrm{~km}$ northwest of Shechem (today Nablus). ${ }^{1}$ The village name preserves the name Sebaste, which was given to Samaria when it was rebuilt by Herod between the years 30-27 BCE to honor the emperor Augustus. Sebaste, a Greek name derived from the word Sebastos, is a translation from the Latin word Augustus, the title which had been granted by the Roman senate in 28 BCE to Emperor Octavian (Octavianus) as a token of esteem for his actions on behalf of the state.

Samaria was situated on a high hill that rises to a height of $430 \mathrm{~m}$ above sea level, in the midst of a fertile and scenic region. Near the city ran an ancient highway that led from Shechem northwards (Fig. 1). This excellent location must certainly have contributed to the importance and prosperity of the city. Its only shortcoming was the lack of a source of fresh water.

\footnotetext{
${ }^{1}$ Tsafrir, Di Segni, Green 1994: 220-221 (Samaria, Sebaste); Avi-Yonah 2002: 90, 151-153.
} 


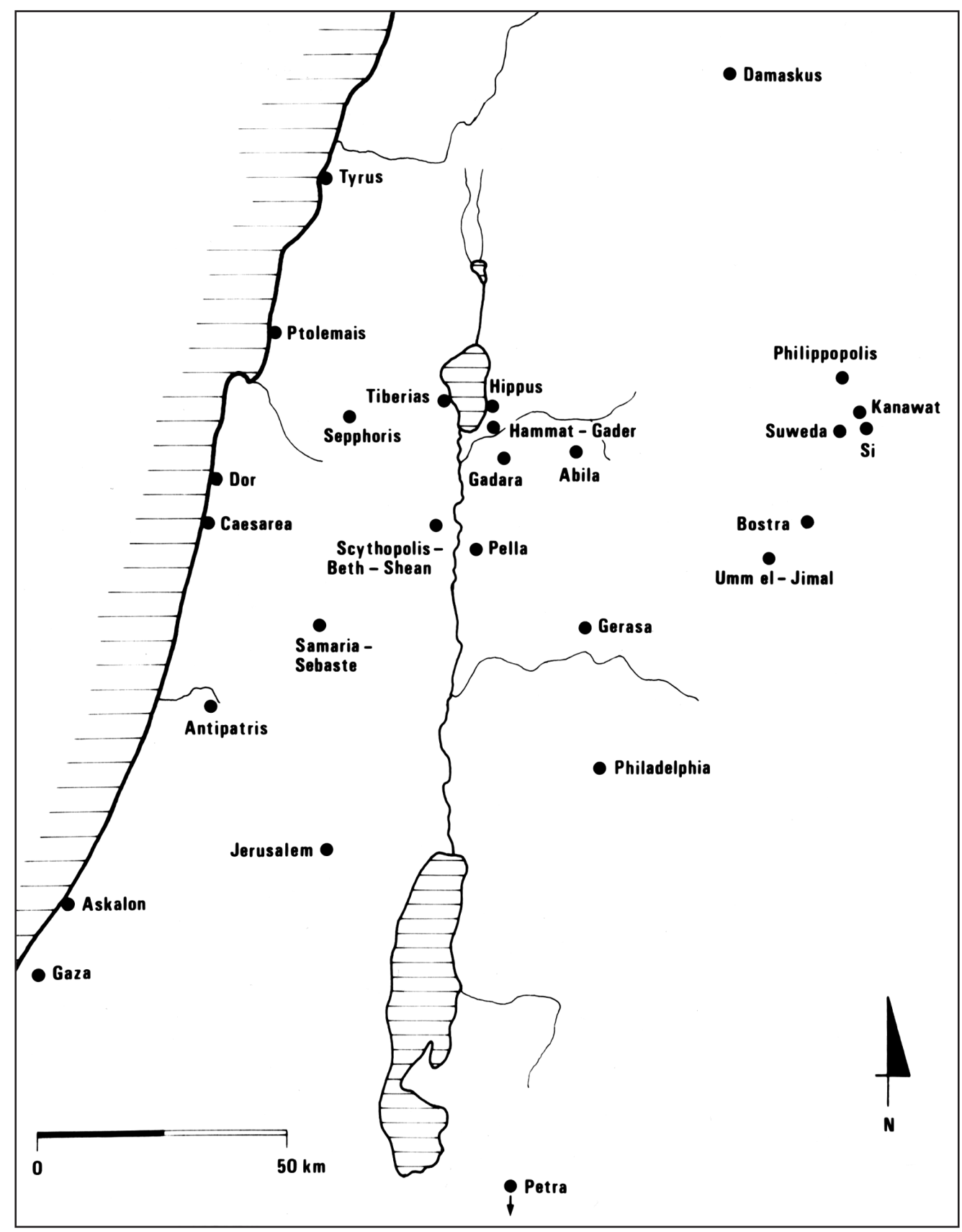

1. Roman Palestine, Southern Syria and Provincia Arabia (Drawing: Z. Friedman). 
In this survey we shall focus on the Herodian Samaria established at the beginning of Herod's reign, although this city was not erected on virgin soil and had been preceded by a few earlier cities. Before describing the Samaria of the Herodian period, we shall briefly review the city of Samaria from the time of its foundation by Omri, King of Israel, until the Byzantine period.

\section{HISTORICAL BACKGROUND}

The story of the founding of Samaria during the reign of Omri, King of Israel (878-871 BCE) is narrated in the Bible with extreme brevity: And he bought the hill Samaria from Shemer for two talents of silver, and built on the hill, and called the name of the city which he built after the name of Shemer, owner of the hill, Samaria (I Kings, 16:24). ${ }^{2}$ The heir of Omri, Ahab (871-852 BCE), continued to build and expand the new capital. With the decline of the Omri dynasty, the status of Samaria was also reduced, but was revived during the reign of Jeroboam II (769-748 вCE). In 722 вCE, Sargon II of Assyria conquered the Kingdom of Israel and Samaria became the capital of a province also called Samaria. The Assyrians settled inhabitants from various countries in it, which caused far-reaching changes in the ethnic composition of the city population (II Kings, 17:24). Apparently, even during the period of Persian rule, Samaria preserved its status as a district capital. When the country was conquered by Alexander the Great (332 BCE), a Macedonian settlement was established there. This is an event of historical implications, because it was the first time that a Greek polis had been founded in the heart of the country, and most of its citizens were Macedonians and Hellenized Syro-Phoenicians. This city was destroyed by the Hasmonaean John Hyrcanus (108 BCE), and according to Flavius Josephus was abandoned for many years.

The year 63 BCE is one of the more significant dates in the history of the Land of Israel. The Roman general Pompey conquered the Seleucid empire and established Provincia Syria in its stead. From then onwards, for centuries, the country would be within the sphere of influence or under the direct rule of Rome. During the period of the Roman governor Gabinius (57 BCE) the settlement of Samaria was revived, and once again gentiles inhabited the new city, which was included within the borders of Provincia Syria. Samaria remained part of that province until $30 \mathrm{BCE}$ when the emperor Octavian decided to incorporate it within the borders of the kingdom of Herod. As a gesture of thanks for this generous act of Octavian, Herod decided to build a new city and to change its name from Samaria to Sebaste, as mentioned above.

Flavius Josephus sums up in brief the story of the foundation of the city: In the district of Samaria he built a city and around it magnificent walls that were twenty ris [furlongs] in length, brought six thousand inhabitants to it and allotted very fertile land to them. In the very hub of the new city he built a monumental temple which he dedicated to the emperor, with a sacred compound around it of three and a half ris in circumference.

\footnotetext{
${ }^{2}$ All quotations from the Bible after Holy Bible 1940.
} 
He called the city Sebaste and gave the citizens an excellent constitution (Jewish War, I, 21: 403). There is a parallel description that is slightly more detailed in Antiquities, XV, 292.

Among the scores of building enterprises that Herod constructed, Samaria held a special place. ${ }^{3}$ The inhabitants of the city gave allegiance to him and supported Herod even before he rose to power and founded the new city. His first encounter with the city occurred ten years prior to its reconstruction, during a time when he was struggling with internal enemies (39-37 вСE). Josephus relates that during the siege of Jerusalem, Herod traveled to Samaria where he married Mariamne, the daughter of Alexander the son of Aristobulus (Antiquities, XV, 467). Was he trying, by the very founding of Samaria, to thank the citizens for remaining loyal to him in his hour of difficulty? Could the very founding of the city and the enormous investment in the large building enterprises that were constructed in it, have all been due to lofty feelings of gratitude? It seems that historians have preferred another explanation, namely that Herod was motivated primarily by political and strategic considerations. Herod regarded the Hellenized population resident in the city as a real pillar of support in his internal struggles. It should be recalled here that even in the centuries after Herod, many of the citizens of the city used to volunteer in the Roman auxiliary forces and were noted for their hostility towards the Jewish inhabitants of the country.

Samaria, like many other cities in the land, was destroyed during the Great Revolt (66-73 CE), but flourished once again during the reign of Septimius Severus (193-211 CE). The Herodian building complexes such as the basilica, the forum, and the sanctuary and temple of Augustus, were renovated and even enlarged. The main street of Samaria became a monumental colonnaded street, and the west gate of the city was reconstructed. In the year $200 \mathrm{CE}$ the city received the status of a Roman colonia. But during the Byzantine period the city began to decline. Unlike Jerusalem and Caesarea, which flourished and prospered in the fourth-sixth centuries CE, Samaria gradually diminished in status in spite of the fact that during the fourth century $\mathrm{CE}$ it served as the see of a Bishop. ${ }^{4}$

\section{RESEARCH HISTORY}

Two archaeological teams excavated in Samaria. The first, which was sent from Harvard University, was active there during the years 1908-1910. Among the members of this expedition were several well known researchers such as Gottlieb Schumacher, George Andrew Reisner, and Clarence Stanley Fisher. The excavations by the Harvard team focused on the central elevated part of the site, in the area of the Israelite citadel. The efforts of the excavators were directed primarily at the structures of the First Temple period, especially the 'Ivory House', which was the palace of the Kings of Israel. At the same time, during the exposure of ancient ruins, some building complexes of the Hellenistic, Herodian and Roman periods were also excavated. ${ }^{5}$ From 1931-1935, a Joint Expedition excavated in

\footnotetext{
${ }^{3}$ Schalit 1969: 358-365; Bru 2011: 83-84, nn. 4-11.

${ }^{4}$ Avigad 1993.

${ }^{5}$ Reisner, Fisher, Lyon 1924.
} 
Samaria. ${ }^{6}$ This term was applied because of the multiple research institutions participating in the expedition, including Eleazar Lipa Sukenik (the Hebrew University of Jerusalem), who represented the Hebrew University of Jerusalem. The expedition was headed by John Winter Crowfoot (the British School of Archaeology in Jerusalem), and among the participants were Kathleen Kenyon (the British School of Archaeology in Jerusalem), Grace Mary Crowfoot (the British School of Archaeology in Jerusalem), and Nahman Avigad (the Hebrew University of Jerusalem). This combined team focused, as the earlier team had done, on the building complexes of the Iron Age, and on broadening the excavated area previously dug by the Harvard team. Included among these building complexes and later structures that were excavated by the Joint Expedition team are Hellenistic fortifications, the Roman colonnaded street, and the complex of the forum, basilica and stadium. Excavations were also partially carried out in the theatre, the Kore temple, sections of the aqueduct, and a few Roman graves, as well as a Byzantine church.

Small scale excavations were conducted in Samaria during the period of Jordanian rule between the years 1965-1967 under the direction of Fawzi Zayadine (Jordanian Antiquities Authority). ${ }^{7}$ During these excavations, the exposure of the theatre that had been partially excavated by the Joint Expedition was completed. Other excavations were conducted along the colonnaded street, the western gate, and the temple of Augustus.

\section{PLAN OF THE CITY}

Unlike Caesarea, Samaria was not planned or constructed as an orthogonal city. This means that its streets did not intersect at right angles and its buildings were not situated within uniformly shaped rectangular blocks (insulae) bordered by the streets. ${ }^{8}$ In Caesarea, on the other hand, which was erected on a level plain, it was possible to lay out a network of insulae of this kind. In Samaria, which was located in a mountainous and deeply rifted region, the method of orthogonal urban planning could not be applied, with the result that the streets and the location of the government building enterprises faithfully reflected the topographical constraints the planners were forced to confront (Fig. 2). Here we should mention that Samaria, in contrast with Caesarea, was not built on virgin soil but on the remains of ancient buildings visible on the surface, which had even been partially used in the construction of new buildings.

The two main building enterprises in the city were the sanctuary and temple in honor of Augustus (the Augusteum) and the theatre, both raised on the acropolis and utilizing the sections of buildings that had been erected in the times of the Kingdom of Israel (nineth-eighth centuries BCE). By contrast, the forum and the basilica, which required a broad and level surface area, were erected where the land was fairly flat and which extended

\footnotetext{
${ }^{6}$ Crowfoot, Kenyon, Sukenik 1942.

${ }^{7}$ Zayadine 1966: 576-580, Fig. 3. On the theatre at Samaria, see: Segal 1995: 77-78, Figs 104-108.

${ }^{8}$ Netzer 2006: 81-93.
} 


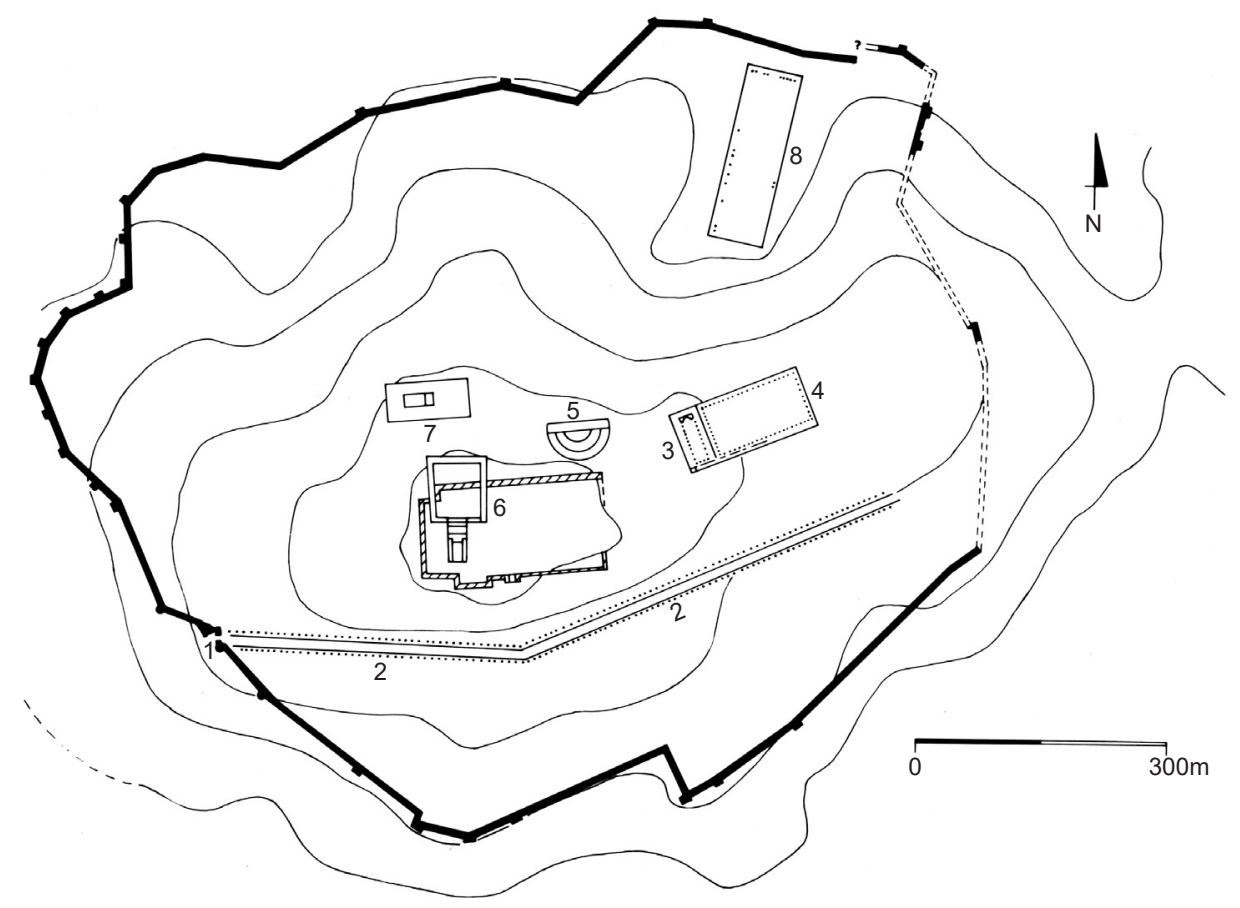

2. Samaria-Sebaste, city plan: 1 . west gate; 2 . colonnaded street; 3 . basilica; 4. forum; 5 . theatre; 6 . temple of Augustus; 7. temple of Kore; 8. stadium (Drawing: Z. Friedman).

eastward and along the foot of the Israelite acropolis. Much effort had to be invested to create a level surface, including the construction of solid supporting walls, quarrying, and extensive earth filling.

When we study the urban plan of Herodian and Roman Samaria, we find it hard to indicate the street network of the city. ${ }^{9}$ There are only two main recognizable routes in the city (Fig. 2). An east-west colonnaded street (Fig. 2:2) begins from the west gate of the city (Fig. 2:1), continues along the south side of the acropolis, and ends in a gate that had once been set into the eastern wall of the city. Another east-west street ran parallel with the south side of the forum and along the north side of the colonnaded street. Very little of this street has been exposed, and besides the fact that it was paved with flagstones, we know nothing more. On the other hand, several sections of the above-mentioned colonnaded street, which was the main traffic route of the city, have been excavated. ${ }^{10}$ Even before the excavations, the hundreds of columns that protruded above the surface had already indicated the lines of this artery, traversing the full length of the city, a distance of about 1000m (Fig. 3). The street consisted of two straight sections which met at a wide angle southeast of the Augustan temple. The western section was $360 \mathrm{~m}$ long while the eastern one was about

\footnotetext{
${ }^{9}$ Segal 1997: 37-40, Figs 37-39.

${ }^{10}$ Segal 1997: 37-40.
} 


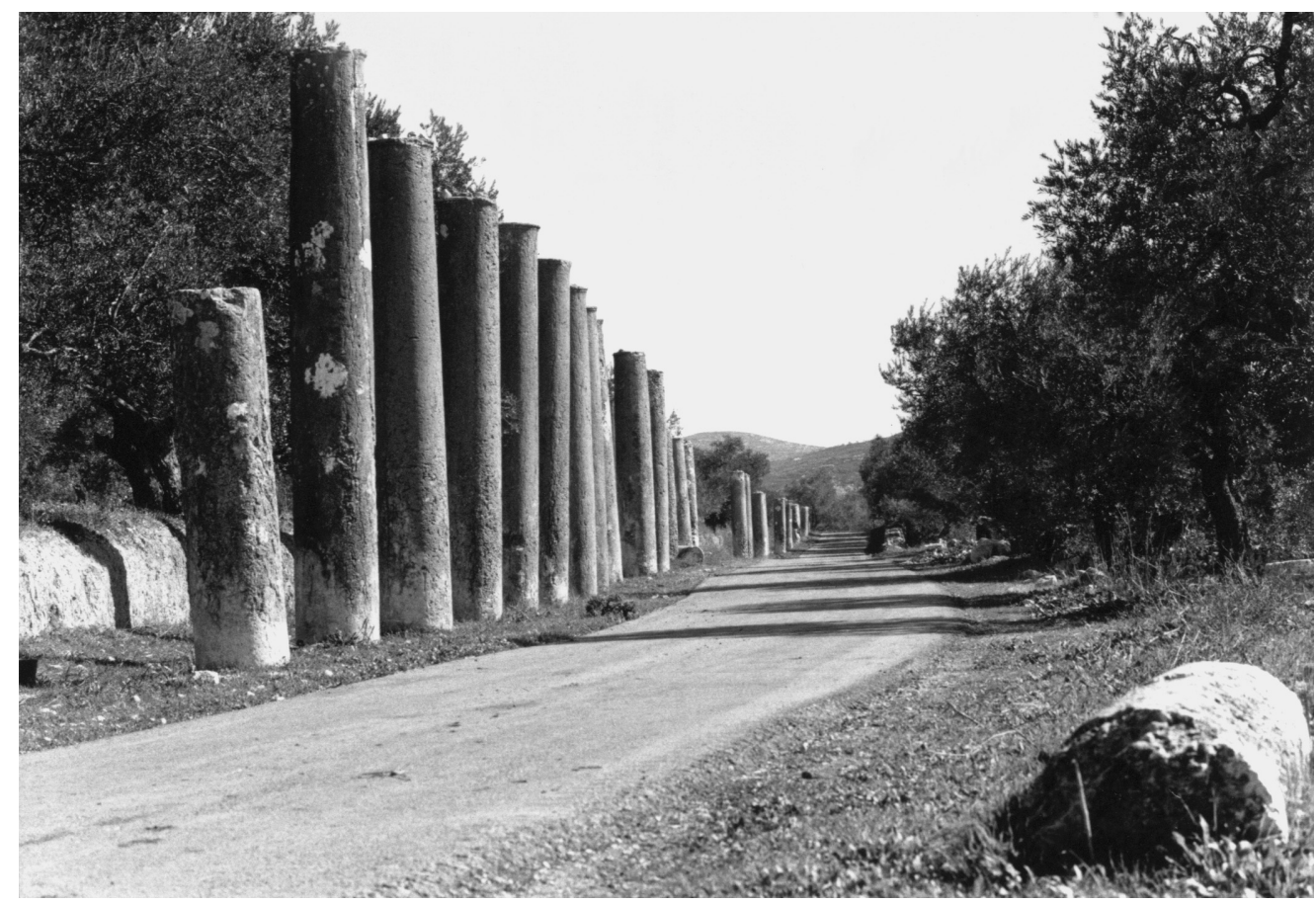

3. Samaria-Sebaste, an unexcavated segment of the colonnaded street (C Israel Antiquities Authority).

$500 \mathrm{~m}$. The eastern end of the street has not yet been exposed. It can be plainly seen that the contours of the land had dictated the layout of the street, which circled around the acropolis on the south side and allowed for easy transition between the two gates of the city. It is reasonable to suppose that stepped streets ran in a north-south direction to connect the area of the forum and the acropolis with the main colonnaded street.

The paving of this colonnaded street must have involved considerable effort since the street passed along the foot of the acropolis built at the top of a fairly steep slope. This required extensive quarrying work as well as the depositing of earth fillings and the erection of supporting walls. The width of the colonnaded street was $12 \mathrm{~m}$ and each of its two sidewalks was $5 \mathrm{~m}$ wide (Fig. 4). Shops with uniform façades were built along the street, and a continuous stretch of single-slope roofs extended between them and the columns of the street. We have here an impressive thoroughfare that is no less grand in its magnificence and magnitude than the colonnaded streets found in other large cities in the Roman East, such as Gerasa, Damascus or Beth Shean (Scythopolis). The excavators of Samaria dated the colonnaded street to the period of emperor Septimius Severus (193-211 CE), and they also assumed that in the earlier stages of this street which should be dated to the time of Herod, a paved street had been laid here, and that it was only in the second century and the beginning of the third century that it was transformed into a colonnaded street. ${ }^{11}$

\footnotetext{
${ }^{11}$ Crowfoot, Kenyon, Sukenik 1942: 52.
} 

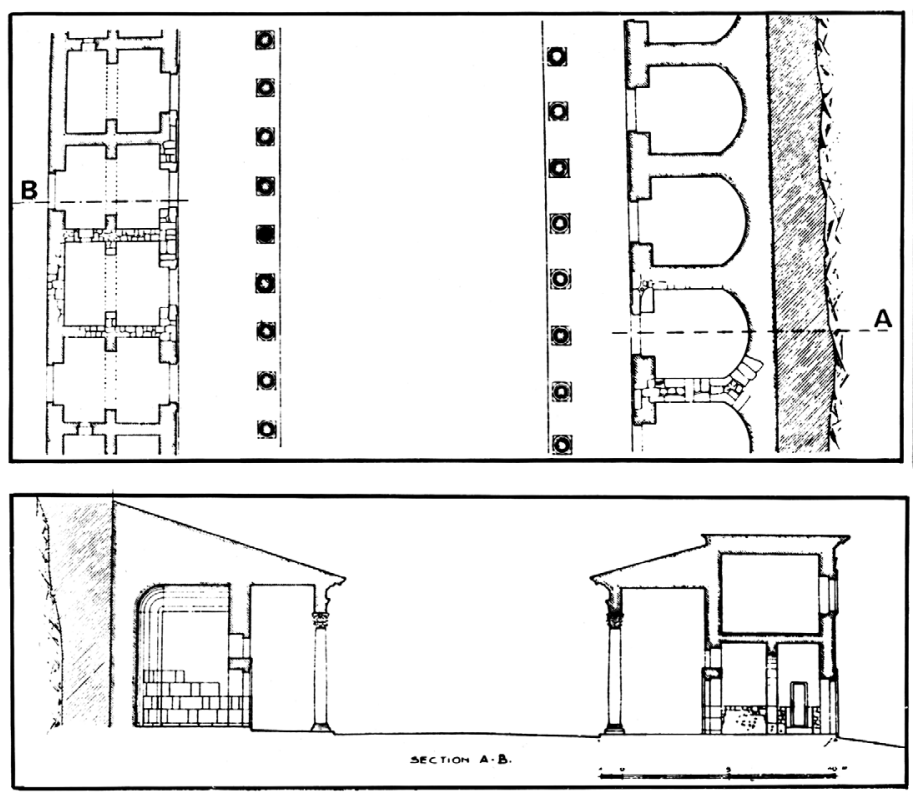

4. Samaria-Sebaste, segment of the colonnaded street, plan and section (Crowfoot, Kenyon, Sukenik 1942: Fig. 32).

\section{FORTIFICATIONS OF THE CITY AND ITS GATES}

The length of the city wall - which was built during the Herodian period - was $3.7 \mathrm{~km}$. Its solid construction and the many towers built into it were an expression of the ambition and bold spirit of the city planners. The walls encompassed an area of about 160 acres. The maximum length of the city from east to west was $1 \mathrm{~km}$, and slightly less than this from north to south. The irregular course of the city wall clearly reflects the topography of this mountainous and rifted region (Fig. 2). It is evident that in Samaria, as in other cities of that period, only a relatively small area was built up, since the city planners also wished to include some agricultural areas within the city perimeter. It appears that the wall had three gates set into it, with the west one serving as the main gate. Another gate was placed in the northern section of the wall, and its location may possibly be determined somewhere near the gymnasium and stadium. Nothing is known so far regarding the precise location of the east gate where the main street of Samaria ended. We give below a brief description of the west gate of the city which is the only one that has been excavated and researched. ${ }^{12}$

The west gate was built with two round towers mounted on square towers of the Hellenistic period (Figs 2:1, 5-6). Each of these round towers was $12 \mathrm{~m}$ in diameter with a solid wall built between them and a gateway of $5.50 \mathrm{~m}$ wide set into it. ${ }^{13}$ It may be assumed that the gate had an arched roof. The façade of the west gate, the side facing

\footnotetext{
12 Segal 1997: 88-89, Figs 88-89.

${ }^{13}$ Segal 1997: 88-89.
} 


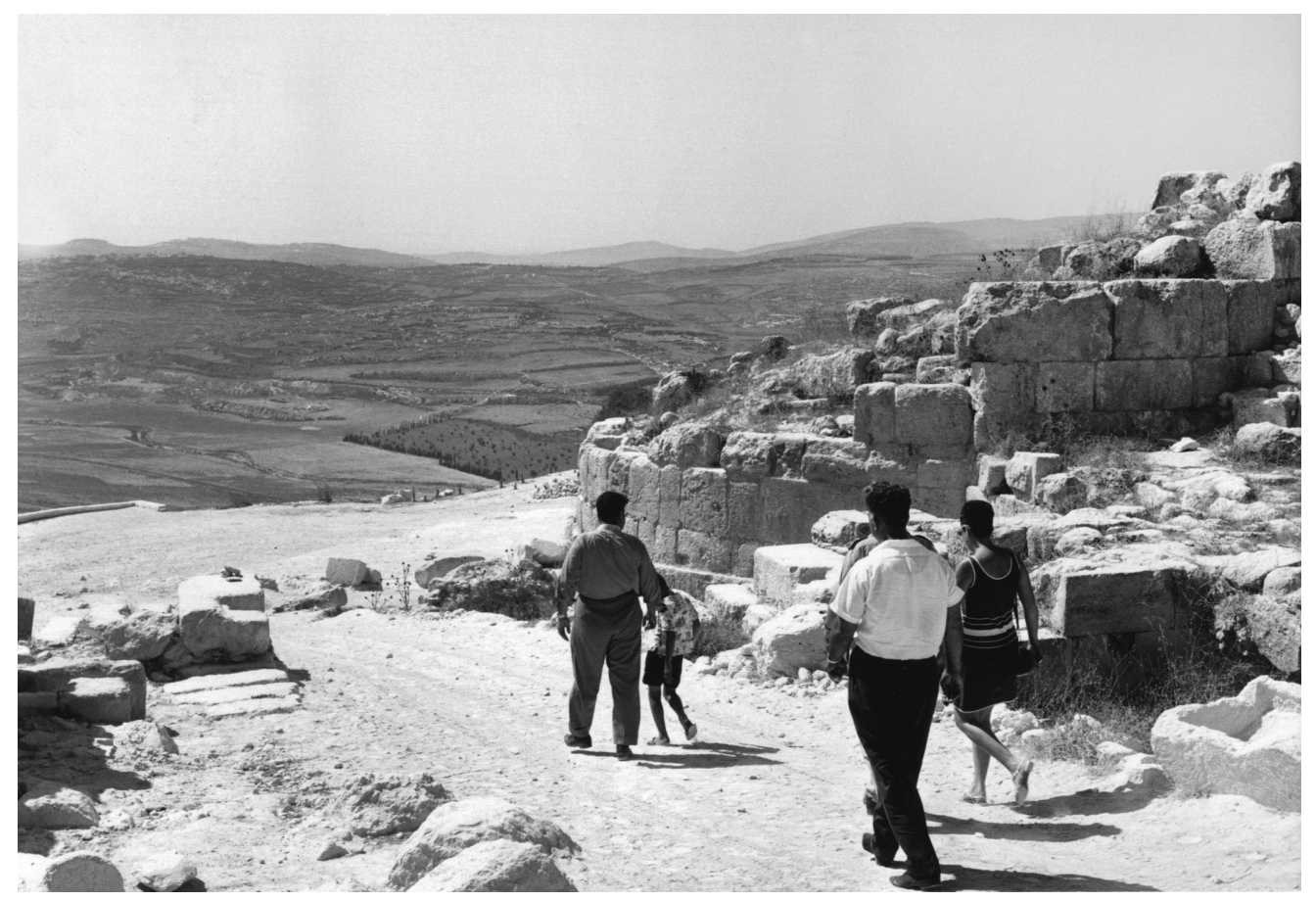

5. Samaria-Sebaste, the west gate, general view (C Israel Antiquities Authority).

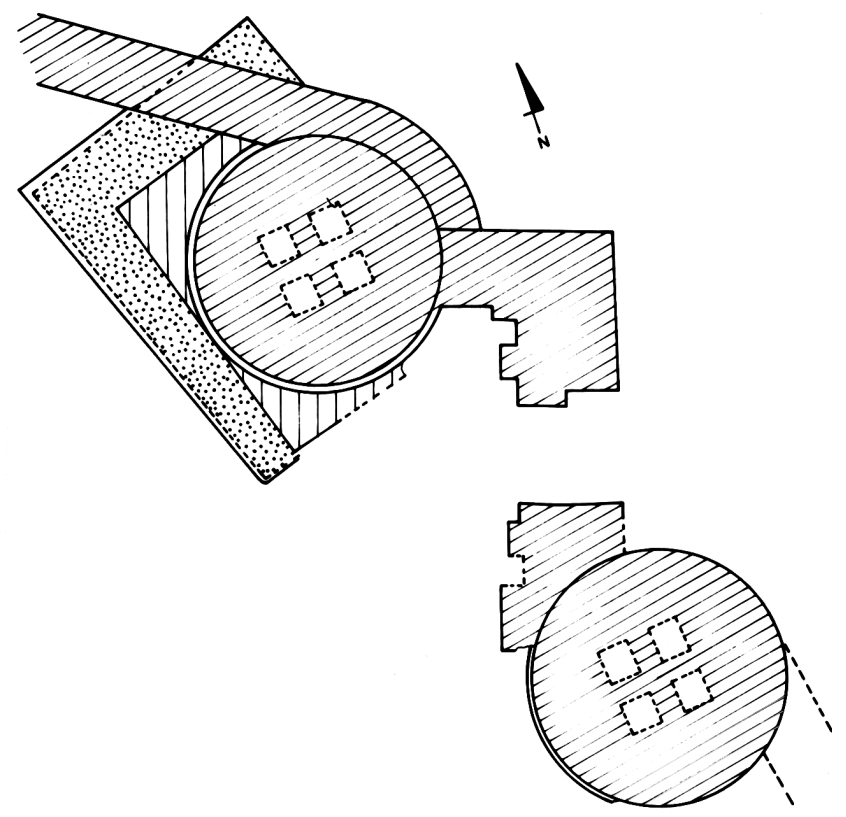

6. Samaria-Sebaste, the west gate, a plan (Drawing: Z. Friedman).

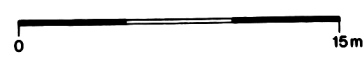


outward, was decorated with pilasters and columns. The towers were obviously built first, and at a later stage the wall with its gateway was constructed between them. The wall is not integrated with the round towers but only adjoin them. In the opinion of the excavators, the round towers are from the Herodian period, while the gate and wall between them with their attractive decorations are from the end of the second or beginning of the third century $\mathrm{CE}{ }^{14}$

\section{THE FORUM AND BASILICA}

\section{THE FORUM}

The forum in Samaria was located on the east side of the acropolis hill and the theatre (Figs 2:4, 7). It is rectangular in shape and its measurements are: $128 \mathrm{~m}$ from east to west and $72.50 \mathrm{~m}$ from north to south. ${ }^{15}$ A broad terrain such as this within a very mountainous and rifted area could only be achieved by leveling work, quarrying and the filling in and shaping of a large and artificial expanse. Stratigraphic examinations revealed that the supporting walls were erected in the first century BCE.

It appears that the forum of Samaria was paved and surrounded by colonnades on all sides. Some segments of these colonnades were clearly noticeable on the surface even before excavation. The column shafts were monolithic, mounted on Attic bases and crowned with Corinthian capitals. The column bases were not placed directly upon stylobates but on high pedestals. Behind the colonnades were walls standing parallel to them, and it may be assumed that single-slope roofs extended between the walls and the colonnade to create a shaded area all around the forum. The excavators of the forum dated the colonnades to the end of the second century $\mathrm{CE}$, but they noted that the supporting walls of the forum were built much earlier, and that the edifice and the basilica next to it had already been erected during the Herodian period. ${ }^{16}$

\section{THE BASILICA}

This impressive structure $(68 \times 32.60 \mathrm{~m})$ was erected parallel to the west side of the forum (Figs 2:3, 7). ${ }^{17}$ This location is of major significance since, according to the specifications of Vitruvius, the Roman architect of the first century BCE, a basilica should be built parallel to one of the short walls of the forum (Vitruvius, Book V, 1). The interior space of the basilica was divided by four colonnades into a central nave and four aisles. Parallel to the short northern wall of the basilica was the tribunal, the place where city officials sat to oversee the proper conduct of trading activities held in this complex. Judges also

\footnotetext{
${ }^{14}$ Segal 1997: 88-89, Figs 88-89.

${ }^{15}$ Segal 1996: 456-458, Fig. 4 (Sebaste).

${ }^{16}$ Segal 1996: 456-458.

${ }^{17}$ Crowfoot, Kenyon, Sukenik, 1942: 31-90; Balty 1991: 396-397, Fig. 197 (Samarie). In general on the basilica, see: Carter 1995: 31-55; Owens 1991: 154; Nünnerich-Asmus 1994: 1-54.
} 


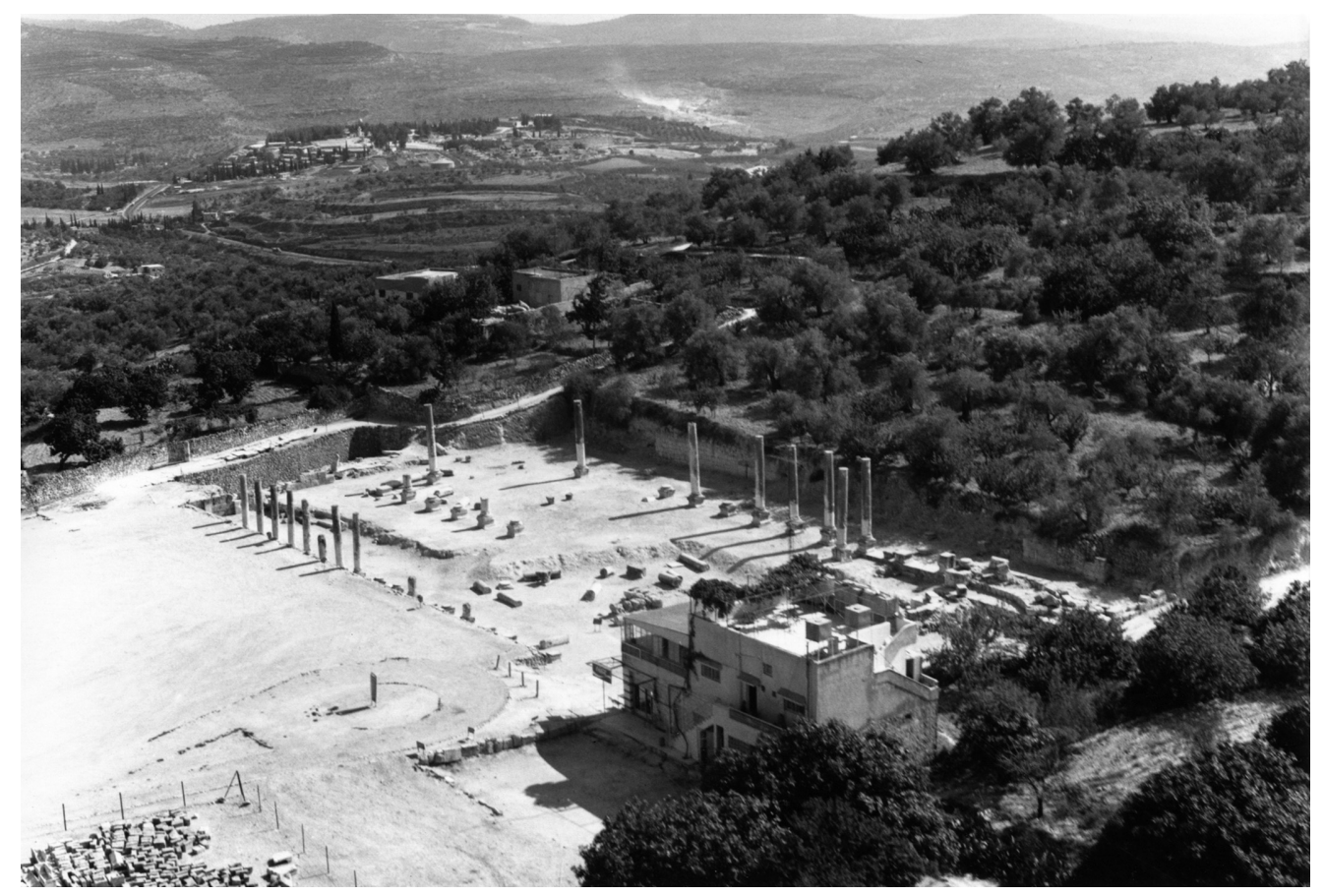

7. Samaria-Sebaste, the forum and the basilica, an aerial view (C Israel Antiquities Authority).

were seated in the tribunal. The latter was designed in the shape of a semicircular niche (apse) within which there were four stepped benches constructed like the seating arrangement in a theatre. The columns shafts of the basilica, like those of the forum described above, were monolithic. They were mounted on Attic bases and crowned with Corinthian capitals. The bases were placed upon high pedestals. The partially exposed remains of the basilica date to the period of Septimius Severus (193-211 CE), and apparently belonged to the renovated structure of the basilica that had originally been erected, like the forum, in the first century BCE during the reign of Herod.

The forum and basilica were clearly planned as a single functional unit, with the basilica serving as the roofed alternative to the open forum. The interrelations between them and also the fact that the basilica faced the forum with one of its long walls - with doorways allowing passage from one to the other - indicate that this was a well planned enterprise. We have here an urban system that drew its inspiration from Roman building traditions as reflected in the book of Vitruvius. ${ }^{18}$

\footnotetext{
${ }^{18}$ Vitruvius devoted fairly extensive space to the basilica in his book. See: Vitruvius, De Architectura 1970: V,1,1-10 (on the forum and basilica). See also another translation with illustrations which gives the text of Vitruvius greater clarity: Vitruvius, Architecture 1999: 63-65, Figs 77-80.
} 


\section{AUGUSTAN TEMPLE AND SANCTUARY (AUGUSTEUM/SEBASTEION)}

The Augusteum, according to its Latin name, or the Sebasteion as it was known in Greek, was excavated twice. At the beginning of the twentieth century an expedition team was sent by Harvard University, and in the 1930s a Joint Expedition was organized, as mentioned above. ${ }^{19}$ Ehud Netzer (the Hebrew University of Jerusalem) returned to the site and critically examined the conclusions of the two expeditions, both with regard to the process of its construction and the design of the sanctuary which was the largest building complex of Herod in Samaria. ${ }^{20}$ It is reasonable to assume that the Augusteum was built close to the time when Samaria was included in his kingdom (28/7 BCE). Its construction is mentioned in brief by Josephus both in The Jewish War (I, 21, 2) and in Antiquities (XV, 298).

The sanctuary was erected at the highest point of the acropolis (Figs 2:6, 8). Since there was insufficient space for the sanctuary forecourt, a broad artificial expanse had to be created, which was achieved by setting up three parallel walls in the form of the letter U. The space between the walls and the space between them and the front of the temple were filled with earth. As a result, a broad rectangular plaza of $85 \times 74 \mathrm{~m}$ was formed opposite the entrance of the temple (Figs 9-10). This plaza, which functioned as a forecourt of the sanctuary, was paved and colonnades were built along three of its walls: the northern, eastern and western ones. The temple and forecourt were constructed along a common lengthwise axis. The entrance front of the temple was at a distance of about $11 \mathrm{~m}$ south of the southern wall of the forecourt. This location was an exceptional one since in most cases a stairway at the entrance front of the temple descended into the forecourt, while the temple itself remained mostly or partly outside the forecourt. Presumably, the reason for this location of the temple was due to Herod's desire to give greater prominence to the temple over its surroundings. Indeed, the floor of the podium on which the temple had been erected, rose $6 \mathrm{~m}$ above the level of the forecourt.

The extensive damage that was done to the Augusteum made it extremely difficult for the excavators to reconstruct the plan of the temple (Fig. 8). The proposal of Netzer, who suggested reconstruction on the typical Roman plan of a 'part peripteros' (sine postico in Latin), seems to this author to be highly plausible. ${ }^{21}$ We therefore have here a temple with columns ranged along the entrance front and the two long walls, with the rear wall of the temple placed close the rear wall of the sanctuary (Fig. 9). This means that unlike peripteral temples, which had columns surrounding them on all sides, as was customary in the Greek world, the Romans preferred the 'part peripteral' plan. The very location of the rear wall of the temple close to the rear wall of the sanctuary, the mounting of the temple on a high podium, and the erection of an impressive stairway at its entrance front,

\footnotetext{
${ }^{19}$ Reisner, Fisher, Lyon 1924: 170-180, Plan VIII, Pls XVII-XXIV; Crowfoot, Kenyon, Sukenik 1942: 123-139, Figs 53-55, Plans IX-X.

${ }^{20}$ Netzer 1987: 97-105, Figs 1-5 (Hebrew, English summary); Ovadiah, Turnheim 2011: 68-71, Pls CICV; Segal 2013: 252-254, Figs 295-300.

${ }^{21}$ Netzer 1987: 97-105.
} 


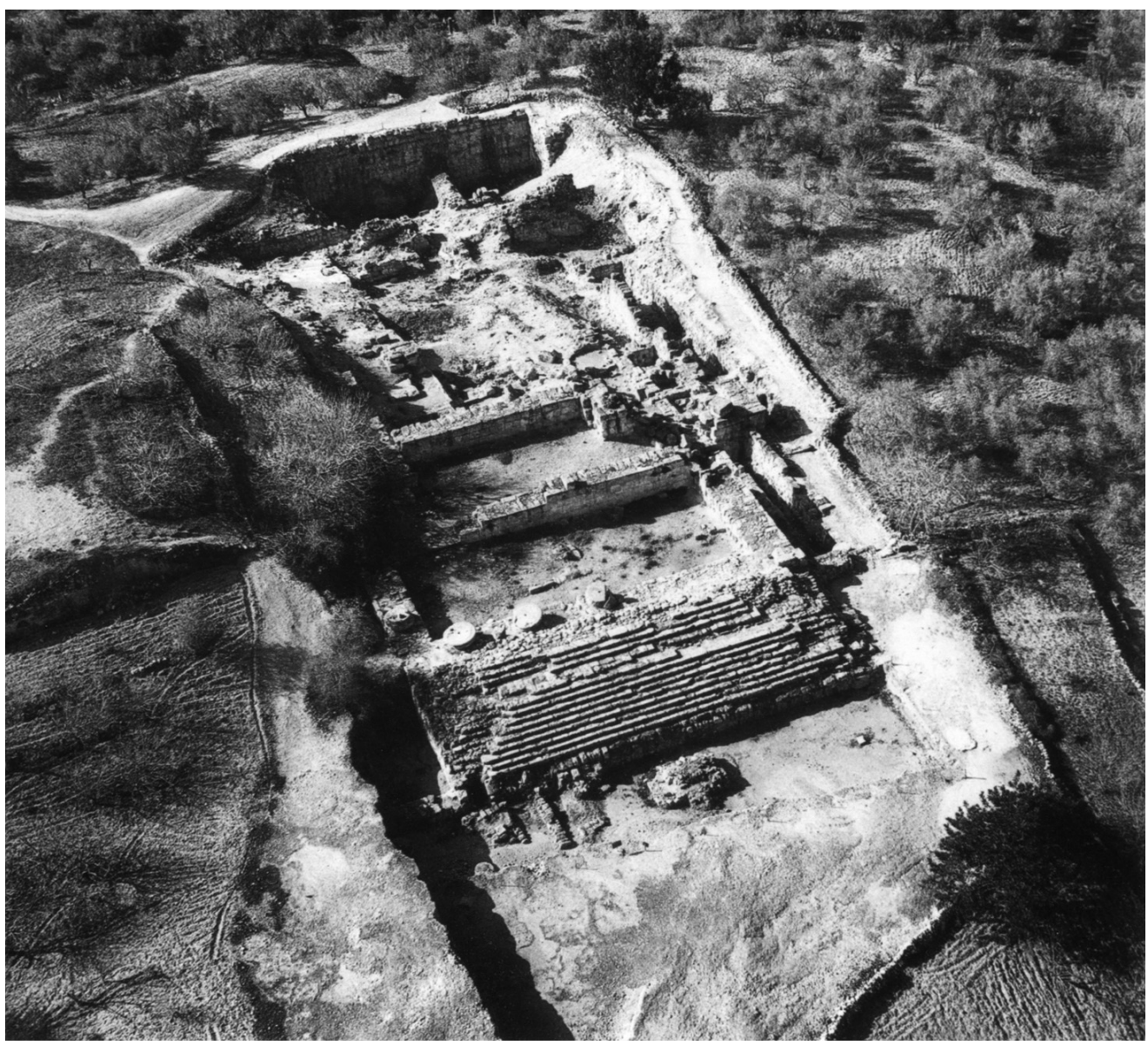

8. Samaria-Sebaste, the temple of Augustus, an aerial view (Holum et al. 1988: Fig. 30).

all turned the Roman temple into an axial and frontal structure that emphasized its presence in the area of the sanctuary (Fig. 10).

In addition to the architectural considerations given by Netzer to support his proposal, we should also take into account the significant fact that Herod, in building this temple for the emperor cult, wished to erect a distinctively Roman type sanctuary similar to other temples of this kind that were being erected by the score in Rome itself as well as in the provinces. The Augusteum, according to the reconstruction of Netzer, had a cella (naos in Greek) in which the external measurements were $28 \times 16 \mathrm{~m}$. The temple could be entered through a single doorway, which was set into the short northern wall. On each of the two long sides of the temple stood seven columns, and six columns stood at the entrance front (the corner columns are counted twice). A stairway enclosed between two terminating walls (antae) of $11 \mathrm{~m}$ in length allowed for easy access from the level of the forecourt to the level of the temple podium. The plan of both temple and forecourt were axial, as mentioned above, symmetrical and frontal. Colonnades were erected around three 
a
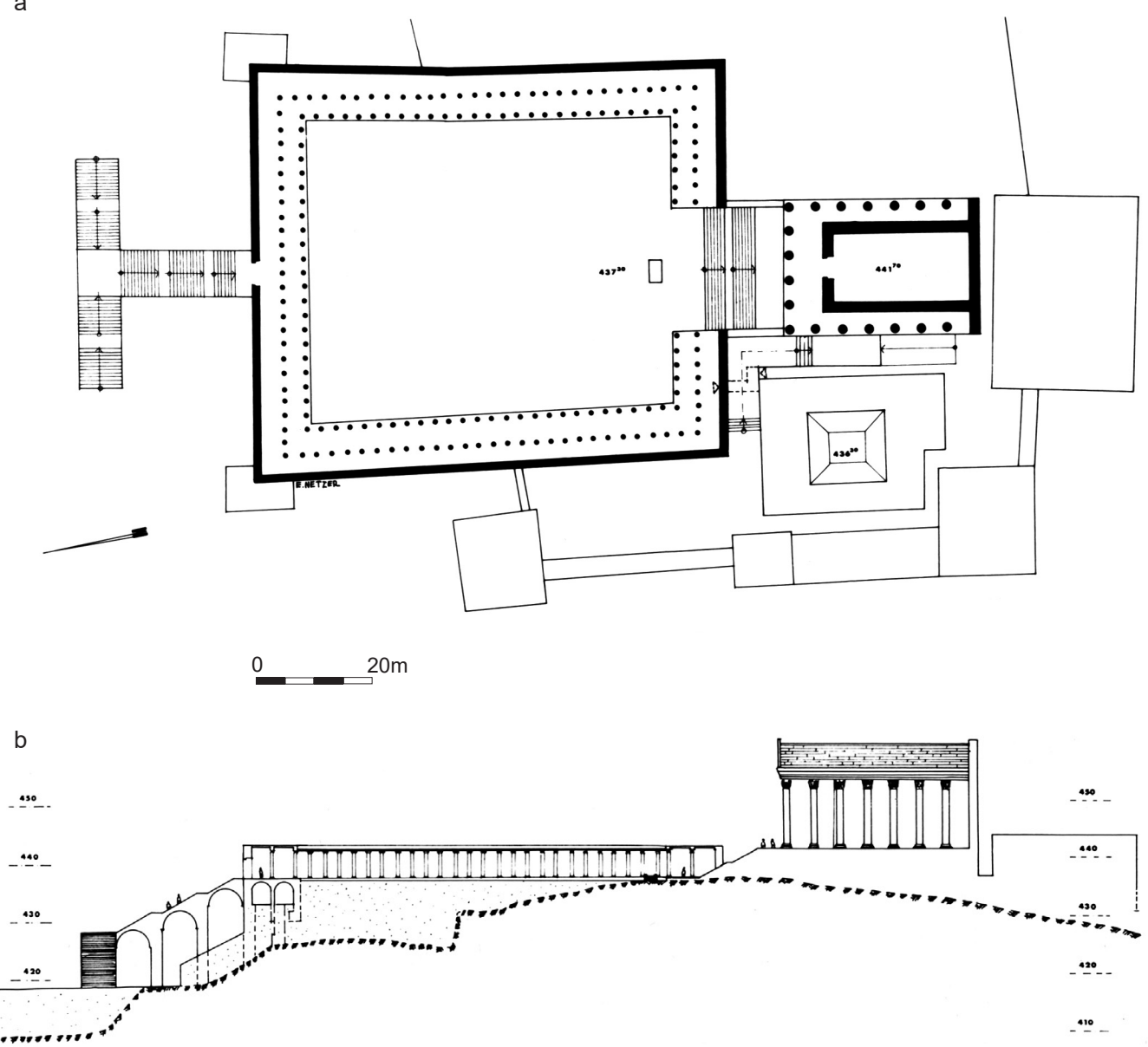

9. Samaria-Sebaste, the Sanctuary and the temple of Augustus, plan and section (Netzer 1987: 102, Figs 4-5).

sides of the forecourt of the temple, on the north, east and west, and they may have even been double colonnades. It is possible that colonnades also stood on the south side of the forecourt (Figs 9a, 10).

The excavations did not answer the question as to where the main entrance to the sanctuary was located. Netzer's proposal to locate the entrance along the same axis as the forecourt and the temple certainly seems plausible and logical. In view of the fact that north of the sanctuary the terrain descends in a northerly direction, it seems reasonable to suppose that a sloping stairway was built here mounted on a series of barrel vaults (Figs 9-10). As mentioned above, during the reign of Septimius Severus (193-211 CE), extensive changes were made in the temple. The latter was lengthened about $11 \mathrm{~m}$ northwards, and as a result of this change, a new stairway was also erected, which descended into the forecourt of the sanctuary. 


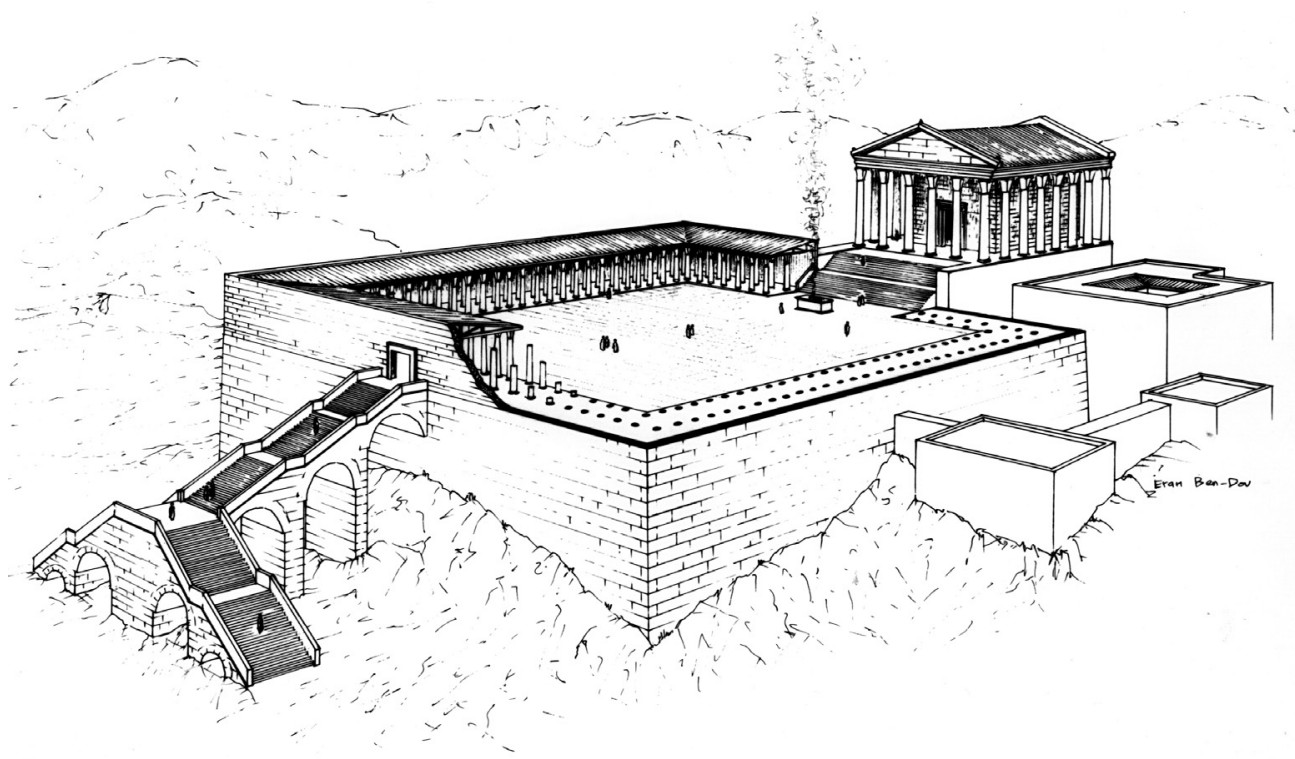

10. Samaria-Sebaste, the Sanctuary and the temple of Augustus, proposed reconstruction (Drawning: E. Ben-Dov; Author's collection).

The Augusteum in Samaria is unique in its outstanding Roman style of construction that drew its inspiration from the traditions of Roman architecture, which had been consolidated at the end of the Republican period and during the Principate (the Augustan period). Like many other building enterprises that were erected in the Land of Israel during the Herodian period, the Augusteum was a foreign model in the architectural panorama of the country at the end of the first century BCE. The very construction in Iudaea of such distinctively Roman buildings testifies to the world outlook of Herod and marks the beginning of the influence of Roman architecture in this region.

\section{SANCTUARY AND THE TEMPLE OF KORE}

The Kore sanctuary is located on a moderate slope north of the Augusteum, at a distance of about 100m from it (Fig. 2:7). The compound was excavated by E.L. Sukenik in 1931 in the framework of the Joint Expedition mentioned above. ${ }^{22}$ The compound is rectangular in shape and measures $85 \times 45 \mathrm{~m}$. The lengthwise axis of the compound is east-west and it was apparently surrounded by colonnades that were erected parallel to its walls. The temenos was paved, at least in part, with rectangular flagstones. The temple was situated in the western part of the compound, precisely along its lengthwise axis, and its foundations rested directly upon the bedrock. So little remains of the temple itself that it is only

${ }^{22}$ Crowfoot, Kenyon, Sukenik 1942: 62-67, Fig. 29; Ovadiah, Turnheim 2011: 67-68; Segal 2013: 254255, Fig. 301. 


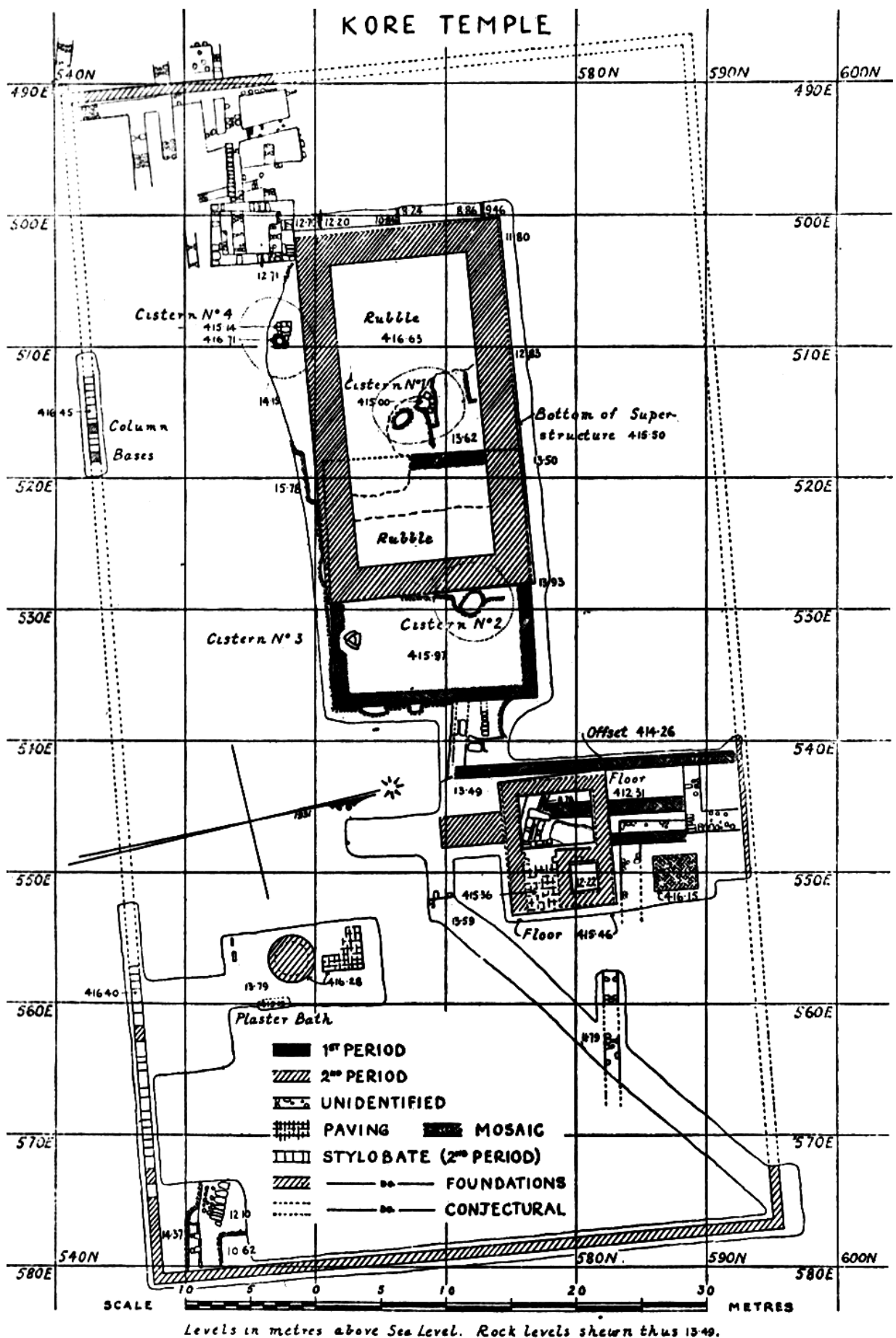

11. Samaria-Sebaste, the Sanctuary and the temple of Kore, a plan: first period - third century BCE; Second period - late second-early third century CE (Crowfoot, Kenyon, Sukenik 1942: Fig. 29). 
possible to determine its general plan (Fig. 11, second period). The measurements of the temple were $35.80 \times 15.50 \mathrm{~m}$. The interior space was divided into two parts. ${ }^{23}$ The eastern part was shorter $(8 \mathrm{~m})$ and apparently served as a vestibule (pronaos), while the western part was the naos. To the east of the entrance front, at a distance of $13 \mathrm{~m}$, the foundations of a rectangular structure were discovered (measurements: 10 x 8m). Most probably these were the foundations of an altar.

A few inscriptions dating from the early Hellenistic to the Roman period, Rhodian handles, and a large number of coins, made it possible to identify the nature of the sanctuary and to determine its chronological framework. Some architectural items and sections of decorative stucco moldings confirm the assumption that at least some of these decorations originated in the Greek world, but others in the East. According to Sukenik, the sanctuary was built in the third century BCE and was dedicated to Isis and Serapis. It was apparently destroyed at the end of the Hellenistic period, and in the Roman period (firstsecond centuries $\mathrm{CE}$ ) the sanctuary and the temple within it were renovated and dedicated to the goddess Kore.

\section{THE THEATRE}

The Harvard University expedition team affirmed on the basis of the contours of the terrain that the theatre of Samaria lay northwest of the city, in the vicinity of the wall. The shape of the natural hollow in this place resembled to a great extent the typical shape of a seating arrangement in a theatre. To the great surprise of the excavators of the Joint Expedition who were in Samaria thirty years later, the theatre was located in an entirely different place (Fig. 2:5). It appears that the theatre of Samaria was erected at the foot of the Israelite citadel (acropolis), and its seating arrangement (cavea) faced northward. The Joint Expedition exposed the theatre only in part, and its excavation was completed by the Jordanian Antiquities Authority at the beginning of the 1960s, as mentioned above (Figs 12-13). ${ }^{24}$

The theatre of Samaria was constructed in an unusual manner. Its cavea was intentionally mounted on sections of ancient walls. Between the northern wall of the acropolis and the level expanse of the orchestra at the foot of the seating system, filling material containing building debris from the period of the Iron Age was heaped up and pressed together. The lower part of the seating area was installed directly upon the bedrock that had been quarried in a stepped formation (as in the theatre in Sepphoris). ${ }^{25}$ The theatre faced northward, its general diameter was about $48 \mathrm{~m}$ and its width across the stage front was $65 \mathrm{~m}$. The diameter of the semicircular seating arrangement was $22 \mathrm{~m}$. The cavea was composed

\footnotetext{
${ }^{23}$ Unmarked on the Fig 11.

${ }^{24}$ Zayadine 1996: 576-580.

${ }^{25}$ Segal 1995: 41-43, Figs 10-13.
} 


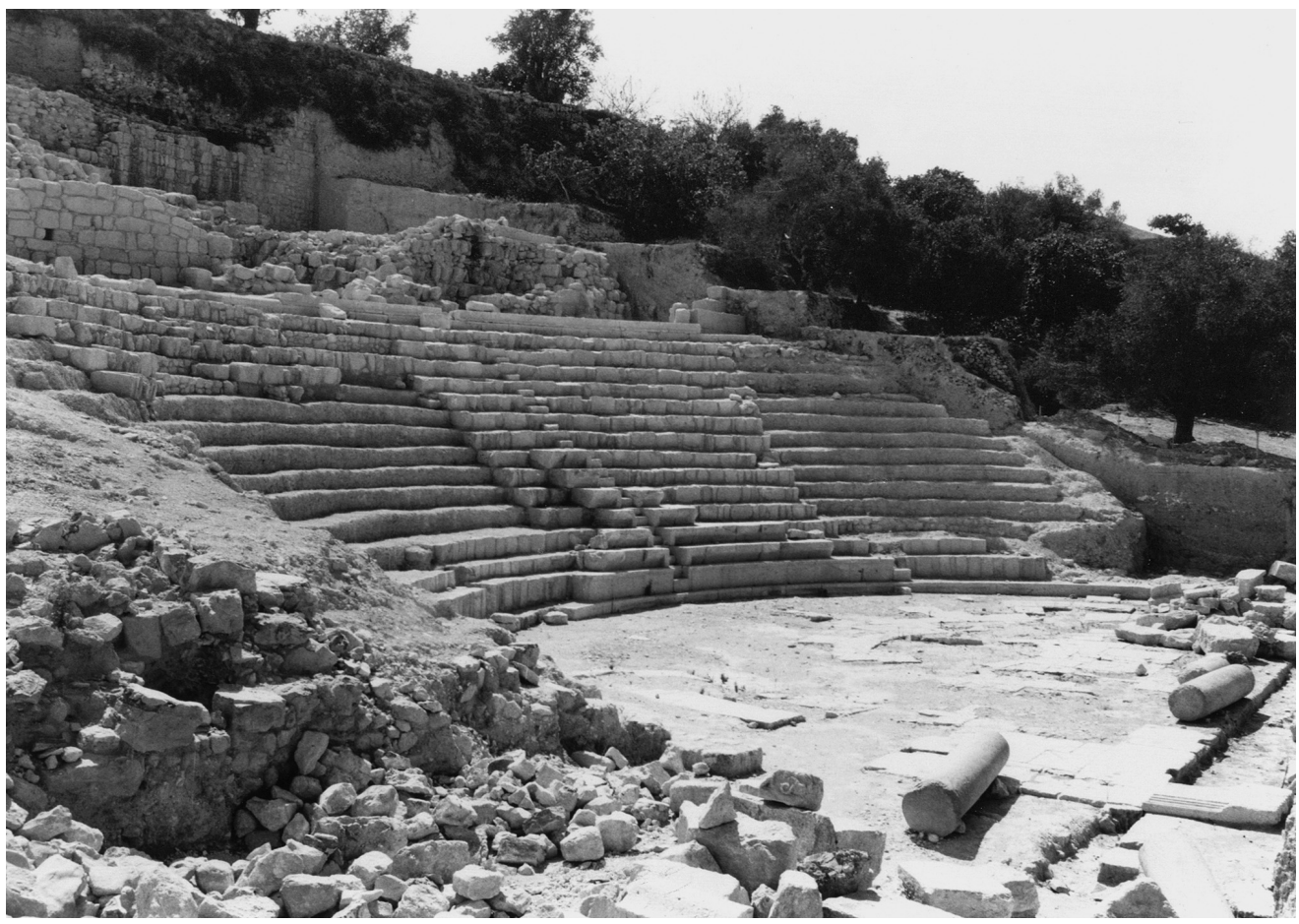

12. Samaria-Sebaste, the theatre, general view of the cavea (C) Israel Antiquities Authority).

of two horizontal blocks, with the lower block (cavea ima) and the upper block (cavea summa) separated by a circuitous passageway (praecinctio) (Fig. 13). In the lower bloc there were 14 rows of seats and in the upper one 10 rows. The orchestra, with a diameter of $15 \mathrm{~m}$, was paved with rectangular flagstones very carefully arranged. Of the stage building (scaena) hardly anything remains. It was built on a pile of earth filling taken from the natural slope and supported on the north by a wall. All this has been washed away. Nothing remains of the stage (pulpitum) as well. On the other hand, there are still some vestiges of the front wall of the stage (proscaenium). The latter, which separates the stage from the orchestra, was designed with small niches, alternatively semicircular and rectangular in shape. The fairly large number of architectural decorative fragments that were exposed in the theatre and in its vicinity confirm that the front wall of the stage building (scaenae frons) facing the pulpitum and the orchestra, and which served as a stage backdrop, was richly decorated.

In the opinion of the excavators, the theatre of Samaria was erected in the second or third century CE. But one cannot negate the possibility that, like the theatre in Caesarea, an earlier stage of its construction can be assigned to the Herodian period. Similar to the forum, basilica and the Augusteum, the theatre in Samaria could have underwent renovation and expansion during the period of Septimius Severus (193-211 CE). 
13. Samaria-Sebaste, the theatre, a plan (Zayadine 1966: Fig. 3).

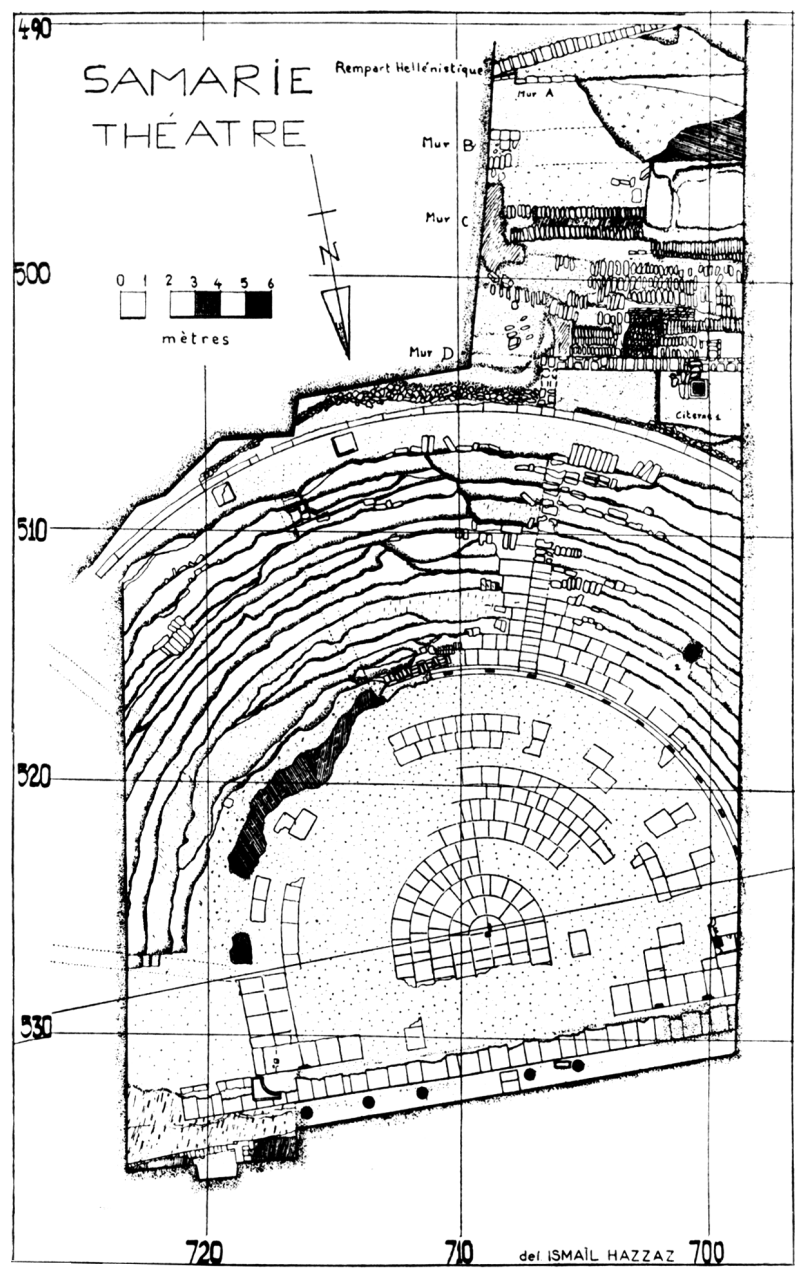

\section{THE STADIUM}

Before describing the stadium exposed in Samaria, it would be worth stating a few preliminary facts about the nature and function of the stadium in the Greek world. ${ }^{26}$ The stadium (stadion in Greek) was a sports facility that was an integral part of a sanctuary such as Olympia, Delphi, or Epidaurus. In the Greek world, sport contests were conducted solely in the framework of religious festivals, held on fixed occasions in honor of the gods worshipped in the various sanctuaries. In the stadia that were located in these sanctuaries, various kinds of athletic competitions were conducted, such as distance running, discus or javelin throwing, or long jumping. Boxing contests and wrestling were also held in the

\footnotetext{
${ }^{26}$ Romano 1993: 1-117; Miller 2004: 87-112; Valavanis 2004.
} 
stadia. In addition to the sanctuary compounds, stadia were also to found in cities (poleis) in connection with the gymnasiums (gymnasion in Greek). The gymnasium was major educational institution to which every citizen was required to send his children, and there was no city (polis) in the Greek world without a gymnasium. The Greeks, besides their general studies, gave an exceptional amount of attention to physical education. Lessons in physical training were conducted in two locations that existed in every gymnasium. The palaistra, which was simply a sandy expanse, was the place where wrestling, boxing and pankration were held, while races of various kinds and other athletics were practiced in the stadium.

From what has been said above, it seems that unlike today, the stadiums in the Greek world were not isolated facilities but were linked with sanctuaries or were part of a gymnasium complex. We may therefore understand that the location of the stadium in Samaria was of far-reaching importance for the civil and cultural character of the city. Since we do not know whether there had ever been in Samaria a sanctuary of the similar kind as in Olympia or Delphi, the conclusion is that the stadium exposed in the dicussed city by the Joint Expedition must have been part of a gymnasium. At the present time, Samaria is the only city not only in the land of Israel but in the entire region, in which a stadium has been discovered. This demonstrates above all else that the inhabitants regarded themselves as the citizens of a polis not only because of its municipal government but also in the cultural sense.

In Samaria the stadium was located in the northeast area of the city, near the wall, taking advantage of a convenient valley extending below the forum (Fig. 2:8). ${ }^{27}$ The stadium was rectangular in shape $(230 \times 60 \mathrm{~m})$, and it was enclosed by walls on all four sides. These walls were covered with wall paintings in the First Pompeian Style, which is characteristic of many Herodian sites such as Herodium, Jericho or Masada. ${ }^{28}$ Colonnades stood parallel with the walls that enclosed a race track (dromos in Greek), and supported single-slope roofs that provided shade along the walls. The very absence of seating arrangements in the stadium strengthens the claim that it served a local gymnasium. The Joint Expedition excavated only a section of the stadium and did not expose the gymnasium. They determined on the basis of the finds they had unearthed that the stadium should be dated to the end of the first century BCE, that is to say to the Herodian period. As noted above, the very existence of a stadium in a city such as Samaria sheds light on the cultural nature of the city and the composition of its population.

\section{CONCLUSION}

The significance of Samaria in the Herodian period should be considered in the context of the king's other building enterprises.

\footnotetext{
${ }^{27}$ Crowfoot, Kenyon, Sukenik 1942: 41-50; Netzer 2006: 92-93; Segal 2009: 99-120.

${ }^{28}$ Foerster 1995: 13-28, Pls I-IV, X-XII.
} 
First of all, it is not by chance that Samaria as well as Caesarea were chosen as a suitable place to erect an Augusteum (Sebasteion in Greek), a temple for the emperor cult. Each of these two sites had a special and also a symbolic value, which according to Herod's view was worthwhile and advantageous to give it some tangible expression. Both Samaria and Caesarea were cities founded at the initiative of the king. Both were given the name of the emperor Octavianus-Augustus. In Caesarea, an impressive port was built that was also named for the emperor - Sebastos, so that both the city and its port actually constituted a political and ideological declaration. They were the new face of a prosperous Hellenistic kingdom, which had succeeded in becoming integrated into the new world order that was gradually taking shape in the Mediterranean basin under the leadership of Rome. But Samaria had a different function. It was the loyal stronghold of the king, the core center of the Land of Israel, a kind of power base that kept watch over two large regions, Iudaea and Samaria, inhabited by two ancient Semitic populations, the Samaritans and the Jews.

\section{References}

Avi-Yonah, M. 2002: The Holy Land: A Historical Geography from the Persian to the Arab Conquest 536 B.C. to A.D. 640, Jerusalem

Avigad, N. 1993: Samaria, [in:] NEAEHL 4, 1300-1310

Balty, J.Ch. 1991: Curia Ordinis: Recherches d'architecture et d'urbanisme antiques sur les curies provinciales du monde romain, Mémoires de la Classe des Beaux-Arts Collection in $-4^{o}, 2^{e}$ série $\mathrm{XV} / 2$, Bruxelles

Bru, H. 2011: Le pouvoir impérial dans les provinces syriennes. Représentations et célébrations d'Auguste à Constantin (31 av. J.-C. - 337 ap. J.-C.), Leiden

Carter, J. 1995: Civic and other Buildings, [in:] Barton, J.M. (Ed.), Roman Public Buildings, Exeter Studies in History 20, Exeter, 31-65

Crowfoot, J.W., Kenyon, K.M., Sukenik, E.L. 1942: The Buildings at Samaria, London

Foerster, G. 1995: Masada V. The Yigael Yadin Excavations 1963-1965. Final Reports: Art and Architecture, Jerusalem

Holum, K., Hohlfelder, R.L., Bull, R.J., Raban, A. 1988: King Herod's Dream: Caesarea on the Sea, New York

Holy Bible 1940: The Holy Bible and International Bible Encyclopedia and Concordance. Authorized or King James version, New York 1940

Miller, S.G. 2004: Ancient Greek Athletics, New Haven

Netzer, E. 1987: The Augusteum at Samaria-Sebaste - A New Outlook, ErIsr XIX, 97-105

Netzer, E. 2006: The Architecture of Herod, the Great Builder, Grand Rapids, Michigan

Nünnerich-Asmus, A. 1994: Basilika und Portikus: Die Architektur der Säulenhallen als Ausdruck gewandelter Urbanität in später Republik und früher Kaiserzeit, Arbeiten zur Archäologie 13, Köln

Ovadiah, A., Turnheim, Y. 2011: Roman Temples, Shrines and Temene in Israel, Roma

Owens, E.J. 1991: The City in the Greek and Roman World, London-New York 
Reisner, G.A., Fisher, C.S., Lyon, D.G. 1924: Harvard Excavations at Samaria 1908-1910, Cambridge, Mass.

Romano, D.G. 1993: Athletics and Mathematics in Archaic Corinth: The Origins of the Greek Stadion, Memoirs of the American Philosophical Society Held at Philadelphia For Promoting Useful Knowledge 206, [Philadelphia]

Segal, A. 1995: Theatres in Roman Palestine \& Provincia Arabia, Leiden-New York-Köln

Segal, A. 1996: Public Plazas in the Cities of Roman Palestine and Provincia Arabia, [in:] Katzoff, R. (Ed.), Classical Studies in Honor of David Sohlberg, Ramat-Gan, 451-487

Segal, A. 1997: From Function to Monument: Urban Landscapes of Roman Palestine, Syria and Provincia Arabia, Oxford

Segal, A. 2009: Sport and Entertainment Facilities in the Land of Israel and in the Graeco-Roman World, Acta Universitatis Lodziensis Folia Archaeologica 26, 99-120

Segal, A. 2013: Temples and Sanctuaries in the Roman East: Religious architecture in Syria, Iudaea/Palestina and Provincia Arabia, Oxford

Schalit, A. 1969: König Herodes: Der Mann und Sein Werk, Studia Judaica 4, Berlin

Tsafrir, Y., Di Segni, L., Green, J. 1994: Tabula Imperii Romani Iudaea-Palaestina: Eretz Israel in the Hellenistic, Roman and Byzantine Periods, Maps and Gazetteer, Jerusalem

Valavanis, P. 2004: Games and Sanctuaries in Ancient Greece: Olympia, Delphi, Isthmia, Nemea, Athens, Athens

Vitruvius, De Architectura 1970: Vitruvius, De Architectura, trans. F. Granger, Cambridge, Mass. 1970

Vitruvius, Architecture 1999: Vitruvius, Ten Books on Architecture, trans. I.D. Rowland, Cambridge, Mass. 1999

Zayadine, F. 1966: Samaria-Sebaste, le théâtre, RevBibl 73, 576-580 


\section{ÉTUDES et TRAVAUX XXX / 2017}

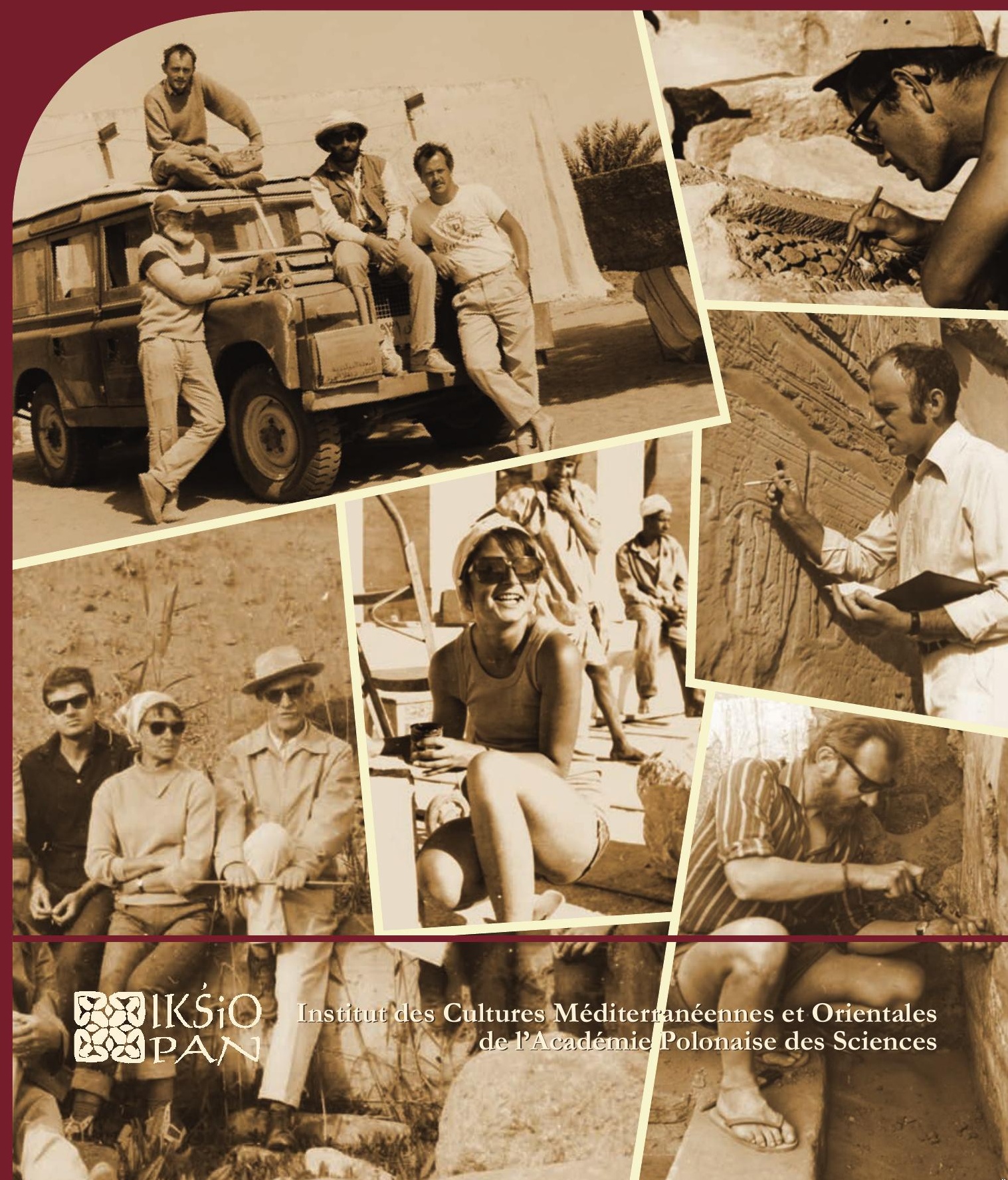




\title{
COMITÉ DE RÉDACTION SCIENTIFIQUE
}

Maciej Makowski - rédacteur en chef

Jadwiga Iwaszczuk - rédacteur et sécretaire de la rédaction

Mariusz Drzewiecki - rédacteur

Maciej G. Witkowski - rédacteur

\section{CONSEIL SCIENTIFIQUE DU JOURNAL}

M. Kobusiewicz (IAE PAS, Warszawa), E. Laskowska-Kusztal (IMOC PAS, Warszawa),

D. Michaelides (University of Cyprus, Nicosia),

J.Ch. Moretti (IRAA-MOM, Université de Lyon 2/CNRS),

D. Raue (Ägyptisches Museum der Universität Leipzig), P. Reynolds (ICREA, Barcelona),

D. Welsby (British Museum, London)

\section{COMITÉ SCIENTIFIQUE DE LECTURE}

J. Holaubek (Institut für Ägyptologie, Wien), S. Ikram (AUC, Cairo),

K. Innemée (Universiteit Leiden), J. McKenzie (Faculty of Oriental Studies, University of Oxford),

N. Strudwick (University of Cambridge), A. Loprieno-Gnirs (Universität Basel),

Ch.E. Loeben (Museen für Kulturgeschichte, Hannover), Y. Tristant (Macquarie University, Sydney),

V.W.J. van Gerven Oei (University of Aberdeen), A. Peignard-Giros (HiSoMA-MOM, Université de Lyon 2/CNRS), J.A. Ostrowski, E. Papuci-Władyka, J. Śliwa (IA JU, Kraków), R. Czerner (WUST, Wrocław), A. Ćwiek (IA AMU, Poznań), M. Wiewióra (IA NCU, Toruń), K. Domżalski

(IAE PAS, Warszawa), K.O. Kuraszkiewicz (DE FOS UW), M. Barwik, P. Bieliński, P. Dyczek, W. Godlewski, D. Ławecka, S. Rzepka, J. Żelazowski, M. Gawlikowski, J. Młynarczyk, A. Niwiński, T. Sarnowski, D. Szeląg, T. Waliszewski (IA UW, Warszawa)

\section{RÉDACTEUR THÉMATIQUE DU VOLUME \\ Barbara Lichocka}

\author{
AIDE RÉDACTION TECHNIQUE \\ Dorota Dobrzyńska, Mariusz Drzewiecki
}

REVUE DES TEXTES ANGLAIS

Jo Harper 
ÉTUDES et TRAVAUX XXX 
INSTYTUT KULTUR ŚRÓDZIEMNOMORSKICH I ORIENTALNYCH POLSKIEJ AKADEMII NAUK

\section{STUDIA i PRACE}

XXX

\section{Ro IKŚSiO \\ ESA PAN}

WARSZAWA

2017 
INSTITUT DES CULTURES MÉDITERRANÉENNES ET ORIENTALES DE L'ACADÉMIE POLONAISE DES SCIENCES

\section{ÉTUDES et TRAVAUX}

XXX

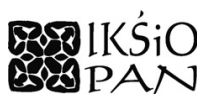

VARSOVIE

2017 
Publication scientifique financée dans le cadre du programme du Ministre de la Science et de l'Éducation Supérieure

« Programme National de Développement de l’Humanistique » pour les années 2016-2021 (projet no 3bH 150099 83)

\title{
HARODOWY PROGRAM ROZWOJU HUMANISTYKI
}

\author{
Copyright (C) \\ Instytut Kultur Śródziemnomorskich i Orientalnych PAN \\ et les Auteurs \\ Warszawa 2017
}

\author{
ISSN 2084-6762 \\ (avant $2011: 0079-3566$ ) \\ e-ISSN 2449-9579 \\ Version première en papier, imprimée en Pologne - 150 copies \\ Version électronique accessible sur \\ http://www.etudesettravaux.iksiopan.pl
}

Édition: Polskie Towarzystwo Historyczne et Wydawnictwo Neriton, Warszawa

Conception générale de couverture : J. Iwaszczuk

Photos de couverture : En haut, à gauche. Vieille Dongola 1991, S. Jakobielski

(debout à gauche), K. Pluskota (debout à droite), B. Żurawski (assis sur le camion)

et P. Wierzbicki (assis sur le camion) (de la collection de B. Żurawski)

En haut, à droite. Palmyre 1964, M. Marciniak au travail (phot. A. Dziewanowski)

Au centre. E. Laskowska-Kusztal au travail (de la collection de E. Laskowska-Kusztal)

En bas, à gauche. Tell Atrib 1962 ; de gauche : T. Biniewski, M. Marciniak, K. Kołodziejczyk,

K. Michałowski, A. Ostrasz, S. Jakobielski et S. Jasiewicz devant eux

(de la collection de IKŚSiO PAN).

En bas, à droite. Vieille Dongola 1976, S. Jakobielski nettoyant le mur (phot. M. Steinborn).

Au centre, à droite, K. Myśliwiec en train des travaux de documentation (de la collection de IKŚiO PAN) 


\section{Table des matières}

BARBARA LICHOCKA

Ergon agathon

Hartwig Altenmüller

$\mathrm{Zu}$ den Feindbildern auf den Zauberstäben des Mittleren Reiches und der Zweiten

Zwischenzeit

Nathalie Beaux

Des $m s w n s w$ de Thoutmosis III à Deir el-Bahari

Briant Bohleke, Nigel Strudwick

A Label for Opening of the Mouth Implements from the Burial of Senneferi (TT99)

and Remarks on the Ritual

Rosa Maria Bonacasa Carra, Nicola Bonacasa

Nuovi dati sugli edifici termali di Sabratha

EDWARD BROVARSKI

A Fragmentary Carrying Chair Scene in Salt Lake City, Utah

Julia Burdajewicz

Wall Painting Decoration from the North-West Church in Hippos-Sussita

of the Decapolis

Mariusz BURDAJEWICZ

From Pagan Temple to Church in Late Antiquity Palestine. A View from

Hippos-Sussita

MAREK ChlodNicki

Early Dynastic Bead Workshops at the Central Kom of Tell el-Farkha.

Patryk ChudziK, Mariusz Caban

Observations on the Architecture of the Tomb of Horhotep in Western Thebes

Krzysztof M. Cialowicz

New Discoveries at Tell el-Farkha and the Beginnings of the Egyptian State.

Amr EL-TiebI

Four Wooden New Kingdom Female Statuettes in the Egyptian Museum, Cairo 


\section{Naguib KanaWATI}

Ritual Marriage Alliances and Consolidation of Power in Middle Egypt during the Middle Kingdom

Adam Łajtar, Jolanta Mlynarczyk

A Faction Acclamation Incised on a Pithos Found Near the North-West Church at Hippos (Sussita)

Adam ŁaJTAR, Grzegorz OchaŁa

Two Private Prayers in Wall Inscriptions in the Faras Cathedral

Adam Łajtar, Anna Poludnikiewicz

Medicinal Vessels from Tell Atrib (Egypt)

JaCeK Michniewicz, Jolanta MlynarczyK

Petrographic Variability of the Fabrics of Wine Jars from Sha'ar-Ha Amakim as a Reflection of Differences in Their Provenance and Chronology

Iwona ModrzewsKa-PianetTI

Les importations d'amphores Dressel 20 en Gaule Cisalpine

Arthur SEgal

Samaria-Sebaste. Portrait of a polis in the Heart of Samaria 409

JOACHIM ŚLIWA

The Motif of a 'Blind Harper' in an Unexpected Place

MONIKA WIĘCH

Searching for the Kitchen in the Early Roman Phase of the 'Hellenistic' House at Nea Paphos (Cyprus)

Abréviations 
THE VOLUME IS PUBLISHED TO CELEBRATE

THE $60^{\text {TH }}$ ANNIVERSARY

OF THE ESTABLISHMENT OF

THE RESEARCH CENTRE FOR MEDITERRANEAN ARCHAEOLOGY POLISH ACADEMY OF SCIENCES

FOUNDED IN 1956

WHOSE MISSION IS CONTINUED BY

THE INSTITUTE OF MEDITERRANEAN AND ORIENTAL CULTURES

OF THE POLISH ACADEMY OF SCIENCES 